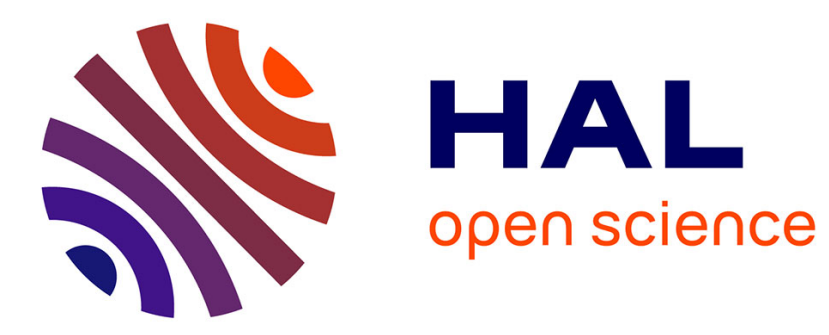

\title{
Influence of Setup Cycles on the Throughput Time of Rush Orders
}

\author{
Friederike Engehausen, Hermann Lödding
}

\section{To cite this version:}

Friederike Engehausen, Hermann Lödding. Influence of Setup Cycles on the Throughput Time of Rush Orders. IFIP International Conference on Advances in Production Management Systems (APMS), Aug 2018, Seoul, South Korea. pp.375-383, 10.1007/978-3-319-99704-9_46 . hal-02164868

\section{HAL Id: hal-02164868 \\ https://hal.inria.fr/hal-02164868}

Submitted on 25 Jun 2019

HAL is a multi-disciplinary open access archive for the deposit and dissemination of scientific research documents, whether they are published or not. The documents may come from teaching and research institutions in France or abroad, or from public or private research centers.
L'archive ouverte pluridisciplinaire HAL, est destinée au dépôt et à la diffusion de documents scientifiques de niveau recherche, publiés ou non, émanant des établissements d'enseignement et de recherche français ou étrangers, des laboratoires publics ou privés. 


\title{
Influence of Setup Cycles on the Throughput Time of Rush Orders
}

\author{
Friederike Engehausen, Hermann Lödding \\ Hamburg University of Technology, Hamburg, Germany \\ \{friederike.engehausen, loedding\}@tuhh.de
}

\begin{abstract}
Many companies use rush orders in production to meet the heterogeneous delivery times customers demand. Rush orders receive high priority in production and thereby achieve short throughput times. In the context of sequencedependent setup times, the throughput time of rush orders can be much higher as they have to wait on their respective setup family. This paper presents two different strategies for accelerating rush orders at workstations with sequence-dependent setup times and shows their influence on the throughput time.
\end{abstract}

Keywords: sequence-dependent setup times, rush orders, production planning and control, job shop production.

\section{Introduction}

Companies react to customers demanding delivery times that are lower than standard throughput times by prioritizing rush orders in sequencing [1]. Nevertheless, the acceleration of rush orders leads to a delay of standard orders $[2,3]$. Trzyna therefore recommends a maximum of $30 \%$ rush orders in a job shop production [1].

In case of a maximum acceleration, the waiting time of rush orders is only determined by the remaining operation time of the preceding order and - if another rush order is in queue - this previous rush order's operation time [1]. Trzyna's model works well if setup times are independent from the sequence in which orders are processed. Nevertheless, setup times often depend on which order has been processed before [4]. In this case, it is common practice to bundle orders in setup families and to define a repetitive pattern for their cyclic production. A changeover between orders within a family requires only minor setup efforts, while the changeover between orders of different setup families causes major setup efforts [5]. As an example, the setup times in the production of abrasive papers have strong sequence-dependencies as a changeover from coarse- to fine-grained paper requires extensive cleaning of up to several hours whereas the changeover from fine- to coarse-grained paper can be undertaken within a few minutes.

Companies then have to decide whether a rush order shall be processed immediately or whether it has to wait until its respective setup family is processed within the setup cycle. A short throughput time of rush orders and a high productivity at the workstation 
by saving as many major setup efforts as possible are therefore conflicting targets when rush orders are integrated in a setup cycle.

This paper is structured in four sections. After this introduction, we present the current state of research, on which the model presented in section three is based. The last section gives a brief summary of the paper and an outlook on planned research.

\section{Current State of Research}

\subsection{Modeling Throughput Time}

The throughput time is one of the internal logistic objectives and can be analyzed on two different levels: the order throughput time and the operation throughput time. The time between an order's release to the production and its completion is referred to as the order throughput time. It summarizes the throughput times of all operations and has often a large share in the delivery time, which is one of the external logistic objectives perceived by the customers [5].

The operation throughput time is defined as the time between the end of the previous operation's processing and the end of the operation's processing. Wiendahl introduces the throughput element to describe an order's throughput at a workstation (Fig. 1). The inter-operation time comprises the post-process waiting time, the transport time and the pre-process waiting time. The setup and processing times are summarized as the operation time. Accordingly, the throughput time can also be calculated as the sum of interoperation and operation time [6].

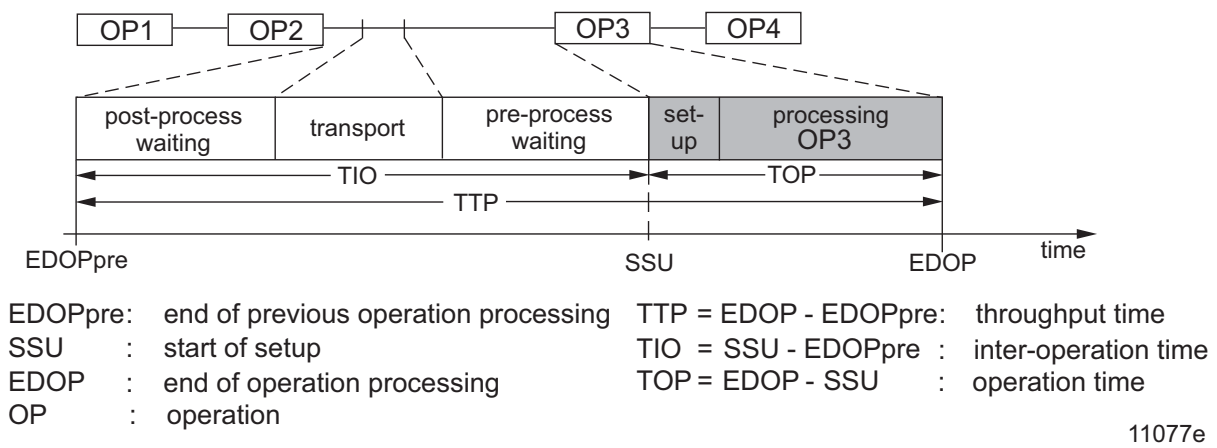

Fig. 1. Operation related throughput element [6]

The operation time of an order is indicated in shop calendar days which is the quotient of the work content and the maximum possible output rate of the workstation. This is necessary to define how much of the workstation's capacity is occupied by the order [7]:

with

$$
\mathrm{TOP}=\frac{\mathrm{wC}}{\mathrm{ROUT}_{\max }}
$$


where TOP is the operation time (SCD), WC the work content (h), ROUT $\max$ the maximum possible output rate ( $h / S C D$ ), LS the lot size (units), $t_{p}$ the processing time ( $\mathrm{min} / \mathrm{unit}), \mathrm{t}_{\mathrm{su}}$ the setup time (min) and TP the lot processing time (min).

\subsection{Modeling the Throughput Time of Rush Orders}

Assuming that rush orders are processed with the highest priority, Trzyna develops a model for rush order throughput times. In his model the inter-operation time only consists of the pre-process waiting time as rush orders are transported preferentially and transportation times can therefore be neglected. In this case, the inter-operation time equals the mean remaining operation time of the previously processed order. Thus, the mean throughput time of rush orders is the sum of the mean remaining operation time of the preceding order and the rush order's operation time [1]:

$$
\mathrm{TTP}_{\mathrm{m}, \mathrm{rush}}=\mathrm{TOP}_{\mathrm{m}, \mathrm{rush}}+\mathrm{TOP}_{\mathrm{m}, \mathrm{rem}, \text { prec }}
$$

where $\mathrm{TTP}_{\mathrm{m}, \text { rush }}$ is the mean throughput time of rush orders (SCD), $\mathrm{TOP}_{\mathrm{m}, \text { rush }}$ the mean operation time of rush orders $(\mathrm{SCD})$ and $\mathrm{TOP}_{\mathrm{m}, \text { rem,prec }}$ the mean remaining operation time of the preceding order (SCD).

However, equation 3 is only valid if no other rush order is in the waiting queue of the workstation at the moment of arrival.

\section{Modeling the Throughput Time of Rush Orders due to Setup Cycles}

\subsection{Accelerating Rush Orders in Setup Cycles}

A simple and often applied sequencing rule with sequence-dependent setup times in job shop production is class exhaustion [8]. Class exhaustion means that orders of a setup family (or setup class) are produced until no further order of this family is left in the queue. The decision, which family is processed next, can be fixed by a repetitive pattern similar to the levelling of assembly lines (e. g. setup family A - setup family B - setup family $\mathrm{C}$ ). The aim of this strategy is to save as many major setup efforts as possible. Both output rate and sequence deviations reached by this sequencing rule can be determined $[9,10]$.

If a rush order arrives at a workstation with sequence-dependent setups, two general strategies may be distinguished. Strategy 1 is the maximum acceleration of the order. Independent from whether the workstation is currently setup for the rush order's family or not, this order is the next to be processed even though there are still orders of the currently processed family in queue. Afterwards, the setup cycle will be continued according to the fixed pattern. Strategy 2 is to wait on the setup family and only to accelerate rush orders within their families. Both strategies have different influences on throughput times, which will be explained in the following section. For an initial assessment, we focus on the maximum and minimum possible throughput time of rush orders caused by these strategies. 


\subsection{Modeling the Influence of Setup Cycles on the Throughput Time of Rush Orders}

Setup cycles influence the throughput time of rush orders. Fig. 2 shows the most important parameters. The following models are based on the assumption that both the mean setup cycle time and the mean operation time of setup families is known. Please see our preliminary studies for a deeper focus on their calculation [9]. Furthermore, we assume a negligible low probability of concurrency between rush orders as their percentage is below $30 \%$ [1].

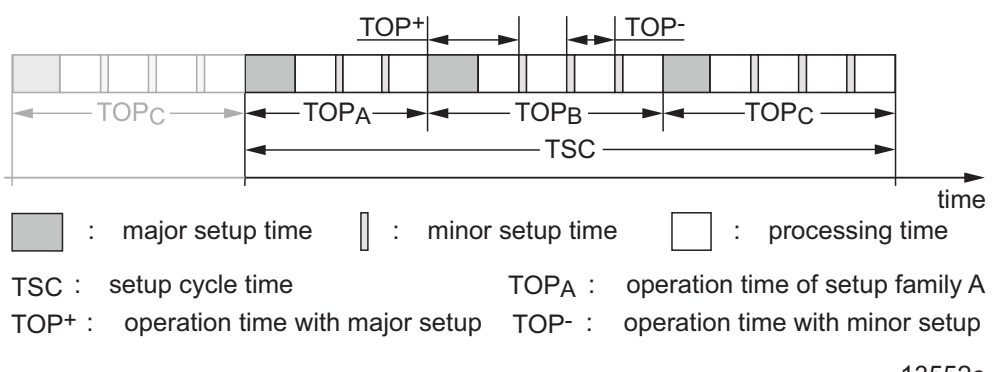

Fig. 2. Main parameters of building setup cycles

Independent from the sequencing rule, the minimum throughput time is determined by the operation time with minor setup effort when the workstation is already setup for the rush order's setup family and the preceding order has just been finished processing meaning the waiting time equals zero:

$$
\mathrm{TTP}_{\text {min,rush }}=\mathrm{TOP}^{-}
$$

where $\mathrm{TTP}_{\text {min,rush }}$ is the minimum throughput time of rush orders $(\mathrm{SCD})$ and $\mathrm{TOP}^{-}$the operation time with minor setup (SCD).

The maximum possible throughput time differs for both strategies, as they influence the waiting time. If a rush order is maximally accelerated, the worst case scenario would be that the rush order will wait during the whole processing of the first order of a setup family requiring a major setup. If the preceding order has been of a different setup family, another major setup is required for the rush order. So for the strategy of a maximum acceleration, the maximum throughput time would equal twice the operation time with major setups:

$$
\mathrm{TTP}_{\text {max,rush,ma }}=2 \cdot \mathrm{TOP}^{+}
$$

where $\mathrm{TTP}_{\text {max,rush,ma }}$ is the maximum throughput time of rush orders when maximally accelerated (SCD) and $\mathrm{TOP}^{+}$the operation time with major setup (SCD).

Simulation runs have shown that $98-99 \%$ of all rush orders had a lower throughput time than the prognosed possible maximum. Higher throughput times result if the unlikely event of two rush orders present in the waiting queue happens and these orders therefore concur for the resources. 
When the rush order has to wait on its setup family, the worst case would be that it arrives when the workstation has just started processing the setup family following right after the rush order's family. Thus, the rush order has to wait until its own family is processed, which equals the length of a setup cycle time less the operation time of the rush order's family. As the rush order is prioritized within its setup family, it will be the first to be processed and therefore requires a major setup. The maximum throughput time of a rush order waiting on the setup family is:

$$
\mathrm{TTP}_{\text {max }, \text { rush,ws }}=\mathrm{TSC} \mathrm{TOP}_{\mathrm{i}}+\mathrm{TOP}^{+}
$$

where $\mathrm{TTP}_{\text {max,rush,ws }}$ is the maximum throughput time of rush orders when waiting on their setup family $(\mathrm{SCD}), \mathrm{TOP}_{\mathrm{i}}$ the operation time of the rush order's setup family $\mathrm{i}$ $(\mathrm{SCD})$ and $\mathrm{TOP}^{+}$the operation time with major setup (SCD).

Simulation runs have shown that $95-100 \%$ of rush orders had a throughput time lower than the prognosed maximum. Obviously, the standard deviation of the throughput time is much higher when the rush order has to wait on its setup family compared to its maximum acceleration. Nevertheless, both strategies have advantages and disadvantages in terms of their influence on logistic objectives, which will be discussed in the following section.

\subsection{Influence of Rush Order Acceleration in a Setup Cycle on Logistic Objectives}

Maximum acceleration. Fig. 3a) shows the results of a simulated workstation with sequence-dependent setup times and a maximum acceleration of rush orders. The box plots depict both rush and standard order throughput times for two different rush order percentages. When rush orders are maximally accelerated, the advantage is that their throughput time can be extremely lowered compared to standard orders. Nevertheless, the standard orders' throughput times are extremely scattering with a maximum of 48 or $190 \mathrm{SCD}$ respectively. The $95^{\text {th }}$ percentiles are also very high compared to the $75^{\text {th }}$ percentile (15 and $29 \mathrm{SCD}$ ) and thereby support the findings.

With a high rush order percentage of $30 \%$, the setup cycle is more often interrupted than with $5 \%$, which means that a lower number of jobs is bundled. This leads to two different effects on the logistic objectives of the workstation: The first effect is that both the median and the third quartile of the standard orders' throughput time is lower than with 5\% rush orders since standard orders do not have to wait that long on their setup family. However, as the setup cycle is not fixed by a repetitive pattern but by the arrival of rush orders, the range of the upper $25 \%$ of throughput times is very wide. The second effect of a lower amount of bundled jobs is that less setup efforts are saved and thus, the output rate is reduced. In the simulation experiment a maximum acceleration with $30 \%$ rush orders leads to a loss of $8 \%$ output rate compared to the simulation with $5 \%$ rush orders. If this is not considered in capacity planning, this strategy would lead to a systematic backlog at the respective workstation.

Additional simulation experiments have been conducted to evaluate the influence of different setup family sizes on the throughput time of rush orders. Fig. 3c) shows the 
results for the strategy of a maximum acceleration. Although the three setup families can be differentiated in high (family A and B) and low volume (family C) families, their percentages do not influence the throughput time of rush orders. A rush order of setup family $\mathrm{C}$ can be accelerated to the same extent as a rush order of family A.

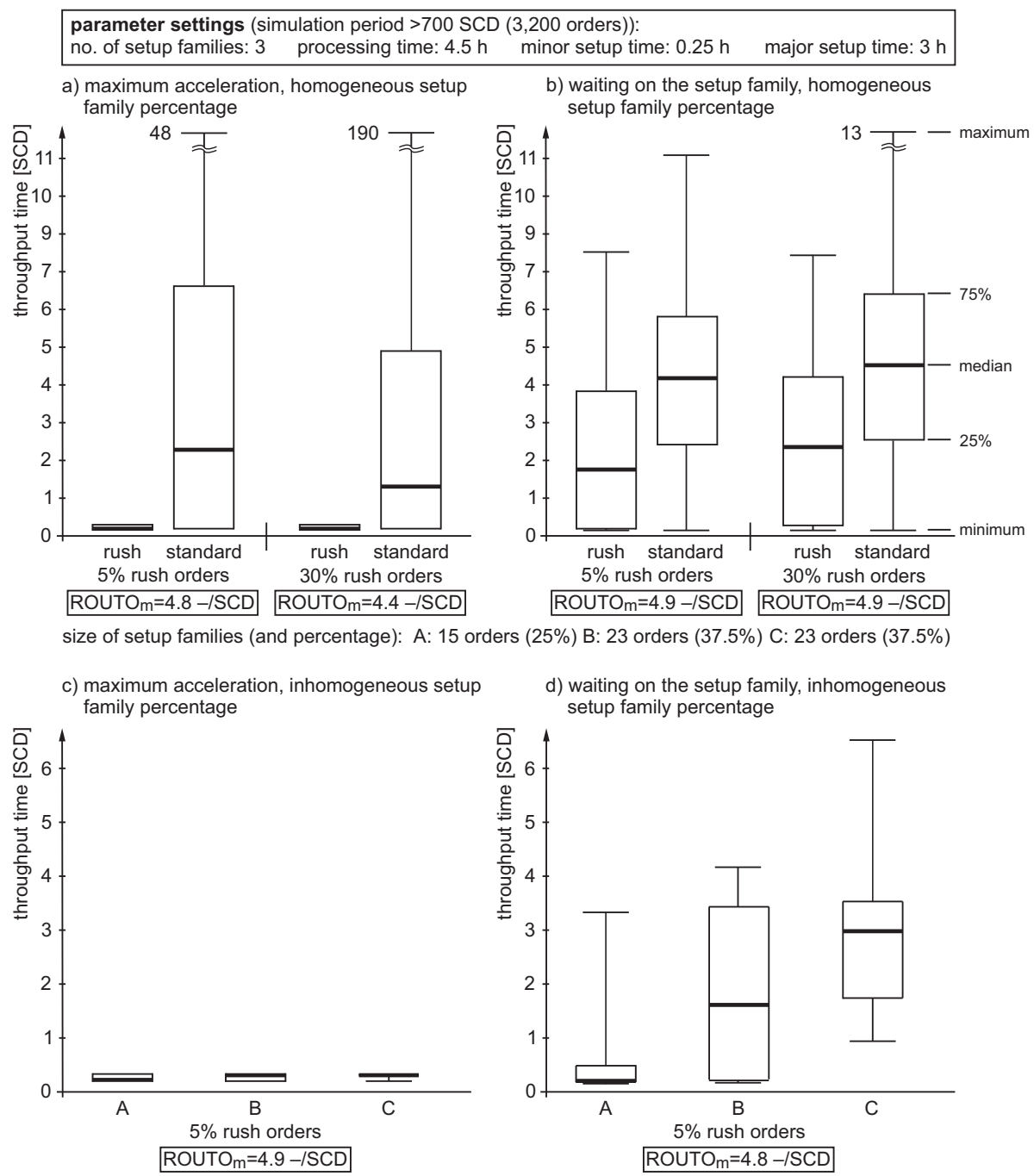

size of setup families (and percentage): A: 64 orders (70\%) B: 13 orders (27\%) C: 3 orders $(3 \%)$

ROUTOm: mean output rate in no. of orders per shop calendar day

Fig. 3. Box plots of throughput time due to rush order acceleration in setup cycles

Waiting on the setup family. Fig 3b) displays the simulation results of a workstation with sequence-dependent setup times and rush orders that are only accelerated within 
their families. Again, the box plots depict both the throughput times of rush and standard orders for two different rush order percentages. The main disadvantage of this acceleration strategy becomes apparent at first glance: rush orders are still accelerated but their throughput time scatters almost to the same extent as the standard order throughput time. Again, the $95^{\text {th }}$ percentile equals similar high values as the maximum throughput times ( 8 and $9 \mathrm{SCD})$. Nevertheless, the advantage of this strategy is that neither a systematic backlog is induced nor are the throughput times of standard orders that severely affected. As the rush order percentage has only little influence on the distribution of throughput times, another advantage of the strategy is its universal applicability.

Fig. 3d) shows the influence of this strategy on the throughput time of rush orders if setup family percentages are very inhomogeneous. A high setup family percentage leads to high setup family sizes and thus to high operation times. According to equation 6 , the higher the operation time of a setup family is, the lower is the potential maximum throughput time of rush orders. Rush orders of setup family A receive the highest acceleration as the probability is very high that this family is currently processed when the rush order arrives. In contrast, rush orders of the low volume variant $\mathrm{C}$ have to wait for a long time until family $\mathrm{C}$ is processed. This causes a high median of throughput times and also high deviations from the mean.

Recommendations. The strategy of a maximum acceleration leads to very low throughput times of rush orders but highly scattering throughput times of standard orders. Furthermore, rush orders make a logistic positioning between a high output rate and a low sequence deviation almost impossible as they generate high turbulences in sequencing. An application of this strategy is only reasonable if the rush order percentage is low, if the acceleration of rush orders is a crucial logistic target and if there is enough capacity available to make up for additional setup efforts.

The strategy to wait on the setup family has the advantage of accelerating rush orders without affecting the throughput of standard orders. Furthermore, the productivity is not affected by rush orders which limits this strategy's applicability not to a low rush order percentage. If percentages of setup families are highly diverging, this strategy causes high mean and highly scattering throughput times for rush orders belonging to low volume families.

To sum up, if a workstation has sequence-dependent setup times companies should thoroughly weigh the rush order prioritization up against increasing productivity by setup-optimized sequencing.

\section{$4 \quad$ Summary and Outlook}

This paper explains the influence of setup cycles on the throughput time of rush orders. Two different strategies to accelerate rush orders within setup cycles have been investigated. The first strategy is to immediately change to a rush order's setup family after finishing the currently processed order. This strategy enables the highest acceleration while resulting in high setup efforts and scattering throughput times of standard orders. The second strategy is to wait on the rush order's setup family according to the regular 
setup cycle and to only accelerate orders within their family. The advantage of this strategy is that neither setup efforts nor throughput times of standard orders are crucially affected.

Companies should be aware of the target conflict between setup efforts and rush order throughput time when deciding how to accelerate rush orders with sequence-dependent setup times. Individual decisions depending on the importance of the respective rush order or a hybrid strategy with a minimum amount of bundled jobs in setup families before changing to the rush order's family are also possible but not yet investigated.

Future research will focus on the probability of the minimum and maximum throughput times modelled in this paper to enable companies to calculate reliable throughput times. Furthermore, for the strategy of an immediate changeover the probability of an interruption of the setup cycle depending on the rush order percentage shall be investigated to assess additional setup efforts. In the end, it is planned to propose a suitable acceleration strategy for rush orders depending on their percentage and setup times.

The authors would like to thank Deutsche Forschungsgemeinschaft (DFG) for funding the project "Development and implementation of a production planning and control for rush orders in the industrial application" (LO 858/16-1).

\section{References}

1. Trzyna, D.: Modellierung und Steuerung von Eilaufträgen in der Produktion. Dissertation Technische Universität Hamburg-Harburg, 2015.

2. Trzyna, D.; Lödding, H.: Modeling the probability of rush order concurrence. Proceedings of the 18th International Working Seminar on Production Economics, Innsbruck, February 24-28, Vol. 1, 467-478, 2014.

3. Plossl, G.W.: Manufacturing Control - The Last Frontier for Profits, Reston Pub., Reston, 1973.

4. Conway, R.W., Maxwell, W.L., Miller, L.W.: Theory of Scheduling. Addison-Wesley, Reading, 1967.

5. Lödding, H.: Handbook of Manufacturing Control. Springer-Verlag Berlin Heidelberg, 2013.

6. Wiendahl, H.-P.: Fertigungsregelung. Logistische Beherrschung von Fertigungsabläufen auf Basis des Trichtermodells. Carl Hanser Verlag, Munich/Vienna, 1997.

7. Nyhuis, P., Wiendahl, H.-P.: Fundamentals of Production Logistics. Theory, Tools and Applications. Springer, Berlin, 2009.

8. Russell, G. R.; Philipoom, P. R.: Sequencing Rules and Due Date Setting Procedures in Flow Line Cells with Family Setups. In: Journal of Operations Management 10 (1991) 4, 524545.

9. Engehausen, F.; Lödding, H.: Produktionskennlinien für Arbeitssysteme mit Rüstzyklen. Wt Werkstattstechnik online 107 (2017) 4, 282-287.

10. Engehausen, F.; Lödding, H.: Modeling Lateness for Workstations with Setup Cycles, in: Lödding, H.; Riedel, R.; Thoben, K.-D.; von Cieminski, G.; Kiritsis, D. (Eds). Advances in Production Management Systems. The Path to Intelligent, Collaborative and Sustainable Manufacturing. IFIP WG 5.7 International Conference, APMS 2017, Hamburg, Germany, September 3-7, 2017, Proceedings, Part I. 